(RESEARCH ARTICLE)

\title{
Edaphic status along altitudinal gradients of Bagale hills forest reserve, Adamawa State, Nigeria
}

\author{
Omijeh Justus Eronmosele ${ }^{1,}{ }^{*}$, Barde Mohammed Mahmud ${ }^{2}$, Jatau David Finchiwa ${ }^{1}$ and Muhammad Aliyu \\ $\mathrm{Ba}^{2}$ \\ ${ }^{1}$ Department of Forestry and Wildlife Management,School of Agriculture, Modibbo Adama University of Technology, Yola, \\ Nigeria. \\ 2 Department of Geography, School of Environmental science Modibbo Adama University of Technology, Yola, Nigeria.
}

Publication history: Received on 26 October 2019; revised on 05 December 2019; accepted on 09 December 2019

Article DOI: https://doi.org/10.30574/wjarr.2019.4.2.0080

\begin{abstract}
An extensive soil survey of the Bagale Forest Reserve, an old reserve in North East Nigeria was conducted, to ascertain its soil status because of exposure and vulnerability to various anthropogenic activities which have been exacerbated by climate change over time. Five fragments within the altitudinal gradients were selected using LANDSAT ETM+ satellite imagery from Google earth. The fragments selected as samples include Tudunwada $(<200 \mathrm{~m})$, Holin $(200-$ $300 \mathrm{~m})$, Modire (300-400m), Lugga (400-500m) and Wurodole ( $>500 \mathrm{~m})$ above sea level. Composite soil samples were collected and sent to the laboratory for analysis. Physical properties of the soil revealed a preponderance of sand (84\%), and low percentages of silt (4\%), clay (6\%) while pores spaces ranged between $28.80-39.49 \%$ in both surface and subsurface. Chemical properties revealed low pH (5.4-6.09), EC (0.06-.10 $\left.\mathrm{m}_{3} \mathrm{~m}^{-1}\right)$, percentage base saturation ranged between (54.08-85.38). The results showed variations in soil properties in the lower, mid and high elevations of the gradient. However, the ANOVA revealed no significant difference in same. The soil of this area will require adjustments and interventions to be able to sustain this forest reserve.
\end{abstract}

Keywords: Edaphic; Fragments; Interventions; Altitudes; Reserve; Bagale

\section{Introduction}

Bagale Hills Forest Reserve is an old ecosystem situated between Latitude $9^{\circ} 11^{\prime} \mathrm{N}$ and $9^{\circ} \mathrm{N}$ and Longitude $12^{\circ} 20^{\prime \prime}$ and $12^{\circ} 30^{\prime} \mathrm{E}$ in Adamawa state, North East Nigeria. It was gazetted as a forest reserve by the state government in December, 1954, [1] long after it had existed as a forest. However, according to [2] (2014) Fufore area of the state that was once dominated by good vegetation and extensive forest as revealed by the 1972 satellite images has by 2014 been alarmingly deforested with significant loss in natural vegetation, increase in bare surfaces, farmlands and built up areas. Common activities carried out in the forests include indiscriminate cutting of trees, intensive farming using wrong approaches, removal of non-forest tree products (NFTP),herding of cattle through the forests for grazing, [3].These practices also cause soil degradation of forest reserves.

One of the most important factors that have effect on the diversity and growth of trees is edaphic, [4]. Forest soils are the initial source of nutrients to plants, store nutrients and serve as habitat to soil microorganisms [5].Many studies on forest soils have showed increased importance of soil physical properties over chemical properties in relation to tree growth.

Soil physical and chemical properties include measurements such as infiltration rates, bulk density, porosity, total nitrogen and available phosphorus. These properties relate with each other and are influenced by other factors such as

\footnotetext{
${ }^{*}$ Corresponding author

E-mail address: jeomijeh@gmail.com
} 
environmental factors and vegetation. Infiltration of water which refers to the downward flow of water from the surface increases water storage for plants and ground water recharge and also reduces erosion [6]. Increased moisture, organic matter and acidity are said to correspond with increasing elevation. Macro and micro nutrients revealed variable responses with nitrogen increase and other macro nutrients decreasing with altitude, [7]. Infiltration is governed by two forces, gravity and capillary action, while smaller pores offer greater resistance to gravity, every small pores pull water through capillary action in addition to and even against the force of gravity. Bulk density has also been reported to be inversely related to total porosity [8]. Bulk density has also been related to natural soil characteristics such as texture, organic matter, soil structure and gravel content [9]. Less than optional bulk density (high porosity) leads to poor water relation and high bulk density (low porosity) reduces exertion and increases penetration resistance limiting plant growth. In grazing areas, infiltration rate has been reported to decrease with increase in stocking of animals while bulk density does not significantly differ with rate of stocking.

Due to the importance of the soil in promoting and sustaining tree growth[10]; [11], the need to assess the current "health" status of forest reserves cannot be overemphasized. Hence the diagnostic soil survey of Bagale forest Reverse (the study area) in different fragments at various altitudes was carried out to access its current status as it has unavoidably been vulnerable to various forms of anthropogenic activities through its current life span of over sixty years. In addition results from such survey should provide baseline information for related future researches and help in the development of agroforestry, management plans. The results can also be used as a template in assessing the status of other forest reserves within the North East sub-region.

\section{Material andmethods}

\subsection{Study Location}

Bagale Forest Reserve is an old reserve located within latitude $9^{\circ} 11^{\prime} \mathrm{N}-9^{\circ}$ and longitude $12^{\circ} 20^{\prime} \mathrm{E}-12^{\circ} 30^{\prime \prime} \mathrm{E}$ in North East Nigeria (Fig 1) with a total area of about 18,000 hectares.

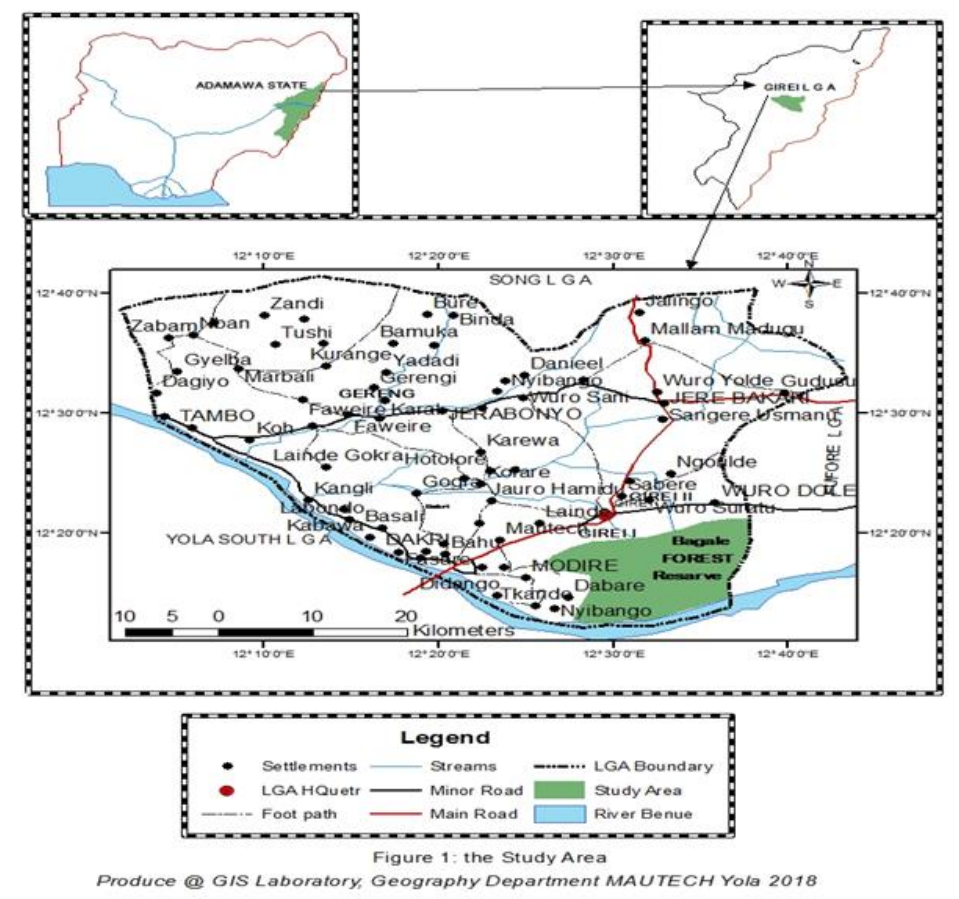

Figure 1 Study area1

The physiography of the reserve is typically undulating, generally of flat plain and a deep to gentle slope surface. The most important landforms are small mountains and flood plains along the River Benue.

The area experiences two distinct seasons, the rainy and dry and two distinct types of temperature, hot and cold [12]. The vegetation is savannah woodland with grass association more or less interspersed with shrubs and trees. It has the characteristics of open biotype with common tree species which include Burkea africana, Tamarindus indica, Acacia 
senegal, Vitex doniana, Adansonia digitata; common grasses include Ipomeatriloba, Andropogon gayanus, Panicum maxicum, Tridax procumbens, Desmodium salicifolium, [13], [14].

\subsection{Digital Maps of the Study Area}

A contour map (fig.2) and the cross section of the study area along a section line from SW to NE (Fig. 3) were produced following the polynomial models adopted by [15]. Elevation above sea level and the distance between plots were measured using a Garmin GPS. The fragments selected and sampled included Tudunwada $(<200 \mathrm{~m})$, Holin $(200-300 \mathrm{~m})$, Modire (300-400m), Lugga (400-500m) and Wurodole ( $>500 \mathrm{~m})$ above sea level.

\subsection{Procedure for Data Collection}

Soil sample collection was done at three points within each quadrat in each quadrat in each of the fragments at 0-40 and 40-80 centimetres depths. The samples were collected at the centre of the plots and at $10 \mathrm{~cm}$ on two sides of a depth at a line drawn passing through the centre of the plots were formed into a composite sample and put in airtight containers and transported to the laboratory for analysis.

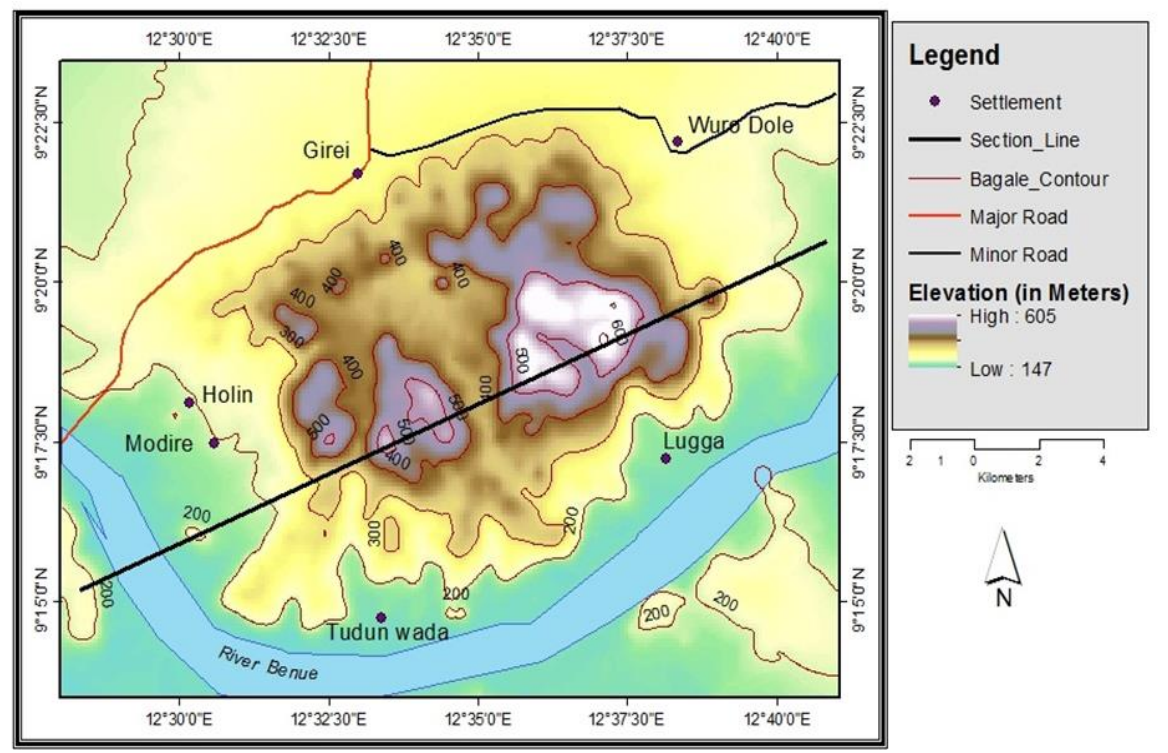

Figure 2 Contour of study area Source: Department of Geography, Mautech, Yola (2018).

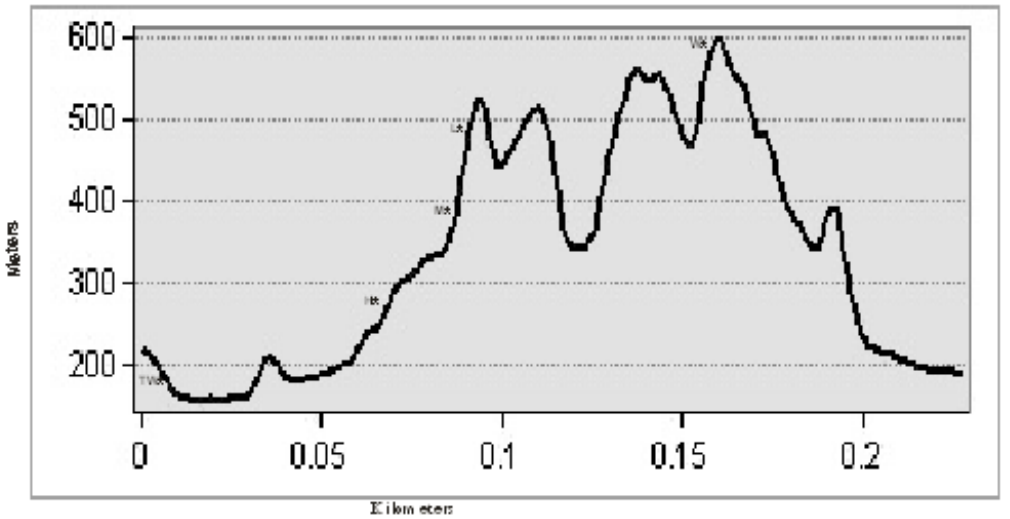

Figure 3 The Cross Section of Bagale Hills Forest Reserve along a Section from SW to NE T/W=Tudun Wada, H=Holin, M=Modire, L=Lugga, W=Wurodole Source: GIS Laboratory, Geography Department MAUTECH, Yola (2018) 


\subsection{Laboratory Analysis}

Physical properties analysed in the surface and sub-surface depths in the fragments included sand (\%), clay (\%), silt (\%) bulk density, $\left(\mathrm{gm} / \mathrm{cm}^{3}\right)$, particle density $\left(\mathrm{g} / \mathrm{cm}^{3}\right)$, porosity (\%), chemical properties analysed in the surface and subsurface included, $\mathrm{P}^{\mathrm{H}}(1: 1) \mathrm{H}_{2} 0, \mathrm{EC} \mathrm{M}_{3} \mathrm{M}^{-1}, \mathrm{OCgk}^{-1}, \mathrm{OM}, \mathrm{TN}\left(\mathrm{Cmol} / \mathrm{kg}^{-1}\right), \mathrm{AVP}(\mathrm{PPM}), \mathrm{Ca}\left(\mathrm{Cmol} / \mathrm{kg}^{-1}\right), \mathrm{Mg}\left(\mathrm{Cmol} / \mathrm{kg}^{-1}\right)$, $\mathrm{K}\left(\mathrm{Cmol} / \mathrm{kg}^{-1}\right)$, Na $\left(\mathrm{Cmol} / \mathrm{kg}^{-1}\right)$, TEB, TEAC, ECEC $\left(\mathrm{Cmol} / \mathrm{kg}^{-1}\right), \% \mathrm{BS}$.

Analysis in the laboratory was carried out following the procedures of [16], [17],[18] , [19],[20] , [21], [22], in the determination of soil $\mathrm{PH}^{\mathrm{H}}$, particle size analysis, bulk density, total porosity, electrical conductivity, organic carbon, total nitrogen, total phosphorus, extractable potassium in soils respectively.

\section{Results}

The $0-40 \mathrm{~cm}$ depth of the Tudun-wada, Holin, Modire, Lugga and Wurodole yielded 86.0, 12,2,2.7, 1.8,31.5; 84.0,10.0, 6 , 2.8, 39.5; 84.0, 10.0, 6.0, 2.5, 1.7, 33.2; 91.0, 6.0, 3.0, 2.9, 1.8, 37.8; 92.0,4.0, 4.0, 1.7, 2.7, 34.8; 90.0,8.0,2.0,2.7,1.8,31.1; percent of sand, silt, clay ,particle density, bulk density and porosity respectively (Table 1) while $40-80 \mathrm{~cm}$ depth of Tudun-wada, Holin, Modire, Lugga and Wurodole exhibited 86.0, 6.0, 2.7, 39.0; 80.0, 6.0, 6.0, 2.0, 50.0, 1.7, 32.8; 90.7,3.0, 3.0, 1.8, 28.8; 91.0, 6.0, 3.0, 2.9, 1.8, 37.8; 94.0, 4.0,2.0, 2.7,1.9, 30.7; percent of sand, silt, clay, particle density, bulk density and porosity respectively,(Table 2).Both surfaces had a textural class of loamy sand.

Table 1 Surface (0-40) soil physical properties of the various fragments

\begin{tabular}{|c|c|c|c|c|c|c|c|c|c|}
\hline Soil parameter & Depth (cm) & F1 & F2 & F3 & F4 & F5 & $\bar{X}$ & SD & $\% \mathrm{CV}$ \\
\hline$\%$ Sand & $0-40$ & 86 & 84 & 84 & 91 & 90 & 87 & 3.32 & 3.81 \\
\hline$\%$ Silt & $0-40$ & 12 & 10 & 10 & 6 & 8 & 9.2 & 2.28 & 24.79 \\
\hline \% Clay & $0-40$ & 2 & 6 & 6 & 3 & 2 & 3.8 & 2.05 & 53.93 \\
\hline Textural Class & $0-40$ & LS & LS & LS & Sand & Sand & Sand & - & - \\
\hline $\begin{array}{l}\text { Bulk density } \\
\left(\mathrm{g} / \mathrm{cm}^{3}\right)\end{array}$ & $0-40$ & 1.83 & 1.67 & 1.67 & 1.78 & 1.84 & 1.758 & 0.08 & 4.75 \\
\hline $\begin{array}{l}\text { Particle density } \\
\left(\mathrm{g} / \mathrm{cm}^{3}\right)\end{array}$ & $0-40$ & 2.67 & 2.76 & 2.5 & 2.86 & 2.67 & 2.692 & 0.13 & 4.94 \\
\hline \% porosity & $0-40$ & 31.46 & 39.49 & 33.2 & 37.76 & 31.09 & 34.6 & 3.81 & 11.01 \\
\hline
\end{tabular}

Table 2 Surface soil $(40-80 \mathrm{~cm})$ physical properties of the various fragments

\begin{tabular}{llllllllll}
\hline Soil parameter & Depth (cm) & F1 & F2 & F3 & F4 & F5 & $\overline{\boldsymbol{X}}$ & Sd & CV\% \\
\hline \% Sand & $40-80$ & 88 & 86 & 90 & 92 & 94 & 90 & 3.2 & 3.5 \\
\% Silt & $40-80$ & 6 & 6 & 7 & 4 & 4 & 5.4 & 1.3 & 24.9 \\
\% Clay & $40-80$ & 6 & 8 & 3 & 4 & 2 & 4.6 & 2.4 & 52.4 \\
$\begin{array}{l}\text { Textural Class } \\
\begin{array}{l}\text { Bulk density } \\
\text { (g/cm })\end{array}\end{array}$ & & LS & LS & LS & Sand & Sand & - & - & - \\
$\begin{array}{l}\text { Particle density } \\
\text { (g/cm }{ }^{3} \text { ) }\end{array}$ & $40-80$ & 1.7 & 1.6 & 1.8 & 1.7 & 1.9 & 1.7 & .09 & 4.9 \\
\% porosity & $40-80$ & 2.5 & 2.7 & 2.5 & 2.7 & 2.7 & 2.6 & .09 & 3.6 \\
& $40-80$ & 32.8 & 39.0 & 28.8 & 34.8 & 30.7 & 33.2 & 3.9 & 11.8 \\
\hline
\end{tabular}

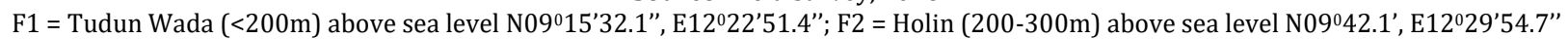
F3 = Modire (300-400m) above sea level N09017'31.7", E12031'08.7”; F4 = Lugga (400-500m) above sea level N09021'13.4", E12035'52.3" F5 = Wurodole (>500m) above sea level) N09022'24.6", E12034'56.3" 
The chemical properties of soils at $0-40 \mathrm{~cm}$ depth of Tudun- wada, Holin, Modire, Lugga and Wurodole revealed $\mathrm{PH}^{\mathrm{H}(1: 1) \mathrm{H}_{2} 0}$ Electrical conductivity $(\mathrm{ds} / \mathrm{m})$, Organic carbon $(\mathrm{g} / \mathrm{kg})$, Organic matter $(\mathrm{g} / \mathrm{kg})$,Total Nitrogen(g/kg), Available phosphorus (ppm), Calcium (cmol/kg), Magnesium (cmol $/ \mathrm{kg})$, Potassium (cmol $/ \mathrm{kg})$, Sodium (cmol/kg), Total Exchangeable Base (cmol/kg), Total Exchangeable Acidity (cmol/kg), Effective Cation Exchange Capacity (cmol/kg), Percentage Base Saturation of 5.5,0.06,6.1, 10.5,0.61,6.6,0.96,0.21,0.77,0.17,2.1,1.8,3.9 and 54.1; 5.5, $.08,12.5,21.5,1.3,6.5,1.9,41,0.44,0.22,3.0,2.0,5.0,60.0 ; 6.3,0.07,10.8,18.6,1.1,6.5,1.6,0.28,0.31,0.26,2.46,2.0,4.5,55.2 ; 5.3,0$ $.11,5.0,8.6,0.50,6.7,2.6,0.21,0.44,0.26,3.5,1.8,5.3,65.9 ; 6.1,0.09,8.1,14.0,0.81,6.5,2.6,0.15,0.26,0.26,3.2,0.8,4.0$ and 80.2 respectively, (Table 3), while the $40-80 \mathrm{~cm}$ depth of the fragments exhibited $6.1,0.10,11.5,19.8,1.2,6.7,2.3,0.09,0.21,0.17,2.7,1.2,3.9,69.4 ; 5.6,0.09,10.3,17.8,1.1,6.5,0.64,0.24,0.33,0.22,1.43,2.40,3.8,3$ $7.3 ; 6.0,0.08,6.4,11.0,0.64,6.6,3.9,0.06,0.36,0.22,4.5,1.8,6.3,71.4 ; 5.9,0.07,6.1,10.3,0.61,6.7,2.3,0.22,0.77,0.26,3.5,0.6,4.1,8$ 5.4; 5.9,0.08,4.8,8.3,0.48,6.6,1.6,0.02,0.21,0.17,2.0,1.2,3.2 and 62.6 respectively (Table 4).

Table 3 Surface (0-40) chemical properties of soils in the various fragments

\begin{tabular}{llllllllll}
\hline Parameter & Depth (cm) & F1 & F2 & F3 & F4 & F5 & Mean & SD & \%CV \\
\hline $\mathrm{pH}(1: 1) \mathrm{H}_{2} \mathrm{O}$ & $0-40$ & 5.54 & 5.54 & 6.26 & 5.34 & 6.09 & 5.73 & 0.42 & 7.27 \\
$\mathrm{EC}(\mathrm{ds} / \mathrm{m})$ & $0-40$ & 0.06 & 0.08 & 0.07 & 0.11 & 0.09 & 0.08 & 0.02 & 23.46 \\
$\mathrm{OCgkg}^{-1}$ & $0-40$ & 6.10 & 12.50 & 10.80 & 5.00 & 8.10 & 8.50 & 3.14 & 36.95 \\
$\mathrm{OM}\left(\mathrm{gm} / \mathrm{kg}^{-10}\right.$ & $0-40$ & 10.52 & 21.50 & 18.62 & 8.62 & 13.96 & 14.64 & 5.40 & 36.87 \\
$\mathrm{TN} \mathrm{Cmol} \mathrm{kg}$ & $0-40$ & 0.61 & 1.25 & 1.08 & 0.50 & 0.81 & 0.85 & 0.31 & 36.95 \\
$\mathrm{AVP} \mathrm{Cmol} \mathrm{kg-1}$ & $0-40$ & 6.56 & 6.49 & 6.49 & 6.71 & 6.49 & 6.55 & 0.10 & 1.46 \\
$\mathrm{Ca} \mathrm{Cmol} / \mathrm{kg}^{-1}$ & $0-40$ & 0.96 & 1.93 & 1.61 & 2.57 & 2.57 & 1.93 & 0.68 & 35.39 \\
$\mathrm{Mg} \mathrm{Cmol} / \mathrm{kg}^{-1}$ & $0-40$ & 0.21 & 0.41 & 0.28 & 0.21 & 0.15 & 0.25 & 0.10 & 39.52 \\
$\mathrm{~K} \mathrm{Cmol} \mathrm{kg-1}$ & $0-40$ & 0.77 & 0.44 & 0.31 & 0.44 & 0.26 & 0.44 & 0.20 & 44.78 \\
$\mathrm{Na} \mathrm{Cmol} \mathrm{kg-1}$ & $0-40$ & 0.17 & 0.22 & 0.26 & 0.26 & 0.26 & 0.23 & 0.04 & 16.99 \\
$\mathrm{TEB}\left(\mathrm{gm} / \mathrm{kg}^{-1}\right.$ & $0-40$ & 2.12 & 3.0 & 2.46 & 3.48 & 3.24 & 2.86 & 0.56 & 19.59 \\
$\mathrm{TEA}\left(\mathrm{gm} / \mathrm{kg}^{-1}\right.$ & $0-40$ & 1.80 & 2.0 & 2.0 & 1.8 & 0.8 & 1.68 & 0.50 & 29.88 \\
ECEC Cmol kg-1 & $0-40$ & 3.92 & 5.0 & 4.46 & 5.28 & 4.04 & 4.54 & 0.59 & 13.03 \\
\%BS & $0-40$ & 54.08 & 59.96 & 55.15 & 65.91 & 80.2 & 63.06 & 10.66 & 16.91 \\
\hline
\end{tabular}

F1 = Tudun Wada (<200m) above sea level N09015'32.1", E12022'51.4'; F2 = Holin (200-300m) above sea level N09042.1', E12029'54.7” F3 = Modire (300-400m) above sea level N09017'31.7”, E12031'08.7”; F4 = Lugga (400-500m) above sea level N09021'13.4”, E12035'52.3” F5 = Wurodole $(>500 \mathrm{~m})$ above sea level N09022'24.6”, E12034'56.3'

Table 4 Sub-surface $(40-80 \mathrm{~cm})$ chemical properties of soils in the five fragments

\begin{tabular}{|c|c|c|c|c|c|c|c|c|c|}
\hline Parameter & Depth (cm) & F1 & F2 & F3 & F4 & F5 & Mean & SD & $\% \mathrm{CV}$ \\
\hline $\mathrm{pH}(1: 1) \mathrm{H}_{2} \mathrm{O}$ & $40-80$ & 6.12 & 5.59 & 6.00 & 5.88 & 5.87 & 5.88 & 0.21 & 3.40 \\
\hline $\mathrm{ECM}_{\mathrm{s}} \mathrm{m}^{-1}$ & $40-80$ & 0.10 & 0.09 & 0.08 & 0.07 & 0.08 & 0.08 & 0.01 & 16.29 \\
\hline $\mathrm{OCg} / \mathrm{kg}^{-1}$ & $40-80$ & 11.5 & 10.3 & 6.4 & 6.1 & 4.8 & 7.82 & 2.91 & 47.65 \\
\hline $\mathrm{OM}(\mathrm{gm} / \mathrm{kg}$ & $40-80$ & 19.83 & 17.76 & 11.03 & 10.25 & 8.28 & 13.48 & 5.01 & 47.63 \\
\hline TN Cmol/kg-1 & $40-80$ & 1.15 & 1.10 & 0.64 & 0.61 & 0.48 & 0.78 & 0.29 & 47.65 \\
\hline AVP Cmol $/ \mathrm{kg}^{-1}$ & $40-80$ & 6.71 & 6.49 & 6.64 & 6.71 & 6.64 & 6.64 & 0.09 & 1.34 \\
\hline $\mathrm{Ca} \mathrm{Cmol} / \mathrm{kg}^{-1}$ & $40-80$ & 2.25 & 0.64 & 3.86 & 2.25 & 1.61 & 2.12 & 1.17 & 52.17 \\
\hline $\mathrm{Mg} \mathrm{Cmol} / \mathrm{kg}^{-1}$ & $40-80$ & 0.09 & 0.24 & 0.06 & 0.22 & 0.02 & 0.13 & 0.10 & 44.72 \\
\hline $\mathrm{K} \mathrm{Cmol} / \mathrm{kg}^{-1}$ & $40-80$ & 0.21 & 0.33 & 0.36 & 0.77 & 0.21 & 0.38 & 0.23 & 99.95 \\
\hline $\mathrm{Na} \mathrm{Cmol} \mathrm{kg-1}$ & $40-80$ & 0.17 & 0.22 & 0.22 & 0.26 & 0.17 & 0.21 & 0.04 & 14.75 \\
\hline TEB(gm/kg & $40-80$ & 2.72 & 1.43 & 4.49 & 3.5 & 2.01 & 2.83 & 1.21 & 34.55 \\
\hline TEA(gm/kg- & $40-80$ & 1.20 & 2.40 & 1.8 & 0.6 & 1.2 & 1.44 & 0.68 & 114.02 \\
\hline ECEC Cmolkg-1 & $40-80$ & 3.92 & 3.83 & 6.29 & 4.10 & 3.21 & 4.27 & 1.18 & 28.73 \\
\hline$\% \mathrm{BS}$ & $40-80$ & 69.41 & 37.33 & 71.39 & 85.38 & 62.61 & 65.22 & 17.65 & 20.68 \\
\hline
\end{tabular}

F1 = Tudun Wada (<200m) above sea level N09015'32.1”, E12022'51.4”; F2 = Holin (200-300m) above sea level N09042.1', E12029'54.7” F3 = Modire (300-400m) above sea level N09017'31.7”, E12031'08.7'; F4 = Lugga (400-500m) above sea level N09021'13.4”, E12035'52.3” F5 = Wurodole (>500m) above sea level 09022'24.6”, E12034'56.3" 


\section{Discussion}

Most Nigerian Savannah soils are highly weathered and fragile with low activity clays, thus making their fertility decline under continuous arable cropping [23]. Generally, soil productivity decline rapidly when vegetation cover is lost and inappropriate management practices are adopted [24], thereby resulting in soil organic matter depletion and reduced agricultural productivity.

High percentage of sand was recorded in both depths of the study area. This agrees with findings of [25], who reported that the dominance of sand contents in Northern Nigeria soils (lithosols) is as a result of sorting, of materials by clay eluviations and surface wind erosion. This report also agrees with the findings of [26] who revealed a high percentage of sand with increase in altitudes in the area he studied which is in the same ecological zone as the study area. These findings also agree with those of [27] who reported a preponderance of sand over sandy loam in his study area. A preponderance of sand in a forest ecosystem could also be related to the parent material from which the sand is developing[28]. The implication of high percentage of sand in an ecosystem is that soil nutrients are leached out of the reach of the trees and hence not available to them for sustainable development.

There was a low percentage of clay with a range of $2-8 \%$ and silt $4-12 \%$ with a clay/sand ratio of $1: 18$. This does not agree with the results of [29] who reported a clay range of between 18 - 24\%; silt 20 - 24\%; sand 51 - 59\% respectively. Also the mean values of sand, silt and clay factions which were 88.5\%, 7.3\%, 4.2\% (in both depths) respectively, which gave the soil a sandy loam texture agrees with the result of [30] who recorded similar trend in a related agroecological zone as the study area. This suggests that the soil at the study area would be prone to leaching due to the high presence of macropores of the dominating sand fraction. This could adversely affect the growth, yield and development of the trees in the study area, because of probable low water and nutrient retention capacity which also aid in high leaching of soil nutrients. This scenario is further exercabated by uncontrollable removal of trees from the forest which further exposes the soil to leaching and erosion. Furthermore, due to intense continuous cultivation as well as the sandy nature of the soils, cations such as $\mathrm{Ca} 2+, \mathrm{Mg} 2+$, and $\mathrm{K}+$ are continuously removed resulting into acidity, as exhibited by the very low and negative values for $\mathrm{pH}$ and ECEC. This invariably explains the reason for the observed low $\mathrm{pH}$, ECFC and OC status of the soil in the study area. The decrease in silt/clay ratio with depth is an indication that sub-soils depths are more weathered than surface depths [31]. Silt/clay ratio are relative higher in the surface depths and decrease with increased depth in the pedons. The relative high bulk density values which ranged between $1.63-1.85 \mathrm{~g} / \mathrm{cm} 3$ is attributed to compaction caused by grazing animals which is a common activity in the study area. Plants perform best in bulk densities below 1.4mgm-3 and 1.6mgm-3 for clayey and sandy soils respectively [32]. One reason for the variation in bulk density on forest floors is the variation in biomass of live small and fine roots $(<5 \mathrm{~mm}$ diameter $)$ and the extent to which they were removed before bulk density was calculated[33]; [34]. The results of the bulk density in the study area which ranged between $1.63-1.85 \mathrm{~g} / \mathrm{cm} 3$ agree with [36] that also recorded almost similar values in bulk density in a similar ecosystem. The least bulk density value obtained under fallow at the soil surface level compared to those obtained under agro forestry species. This could be as a result of mart layer formed by low quality liter which does not decompose easily, thereby lowering soil compaction by rain drops. The implication is that soils under agro forestry tree species are more compacted, thereby increasing the water holding capacity of the soil than the soil under natural forest which drain and dry fast due to high porosity [37]. Generally, the observed mean range of bulk density in the study area $(1.63-1.85 \mathrm{gm} / \mathrm{cm} 3)$ is ideal for optimum root growth and this agrees with the findings of [37]. The soils of the area are found to contain relatively appreciable amount of clay content between $2-8 \%$, this may be attributed to eluviations and pedoturbation processes. The silt content of the soil was observed to slightly increase with increasing depth in almost all the profiles. [38] and in their studies of soils in the Savannah region of Northern Nigeria mentioned the influence of harmattan dust in contributing silt to soil. The silt/clay ratio ranged from 0.35 to $2.19,0.35$ to1.27 and 1.11 to 1.46. [39] reported that "old" parent materials usually have a silt/clay ratio below 0.15 while silt/clay ratios above 0.15 are indicative of "young" parent materials. Results of the study from this study area show that all the soils have silt/clay ratio above 0.15 indicating these soils have high degree of weathering potential.

Growth could also be inhibited due to high bulk density because of soil resistance to root penetration, poor aeration, slow movement of nutrients and water and build-up of toxic gases and root exudates,[40]; [41]; [42], reported that particle size density values increase with soil depth. Similar results were also reported by [43] in soils of Samaru area, a location also in the Northern Guinea Savannah as the study area. Porosity values ranged from $25-40 \%$ ( $35 \%$ average), 34 to $47 \%$ (41\% average), [44] reported similar values in the soils of Zaria, Kaduna State also in the Northern Guinea Savanna,.[45], recommended that soils having porosity of over $50 \%$ and $45-50 \%$ of volume are good agricultural soils. Soil porosity is lower in the study area and this may be attributed to the clayey nature of the soils.

PH value of the soils in the study area ranged between 5.34 and 6.26, and was observed to increase or decrease irregularly with increasing depth. Similar trends were observed and reported by [46] According to [47] a pH range of 
5.5 to 7.0 is the preferred range for most crops. This might be due to irrigation activities going on in an area. Organic matter is generally low in the soils. According to [48] organic matter in the soil is rated as; $>20 \%$ very high, $10-20 \%$ high, $4-10 \%$ medium, $2-4 \%$ low and $<2 \%$ very low. Low organic matter content of the soils in Sokoto State has been attributed to factors such as continuous cultivation, frequent burning of farm residues commonly carried out by farmers in the area which tends to destroy much of the organic materials that could have been added to the soil [49]. Furthermore, [50] stated that low organic matter content in soils of Sokoto area could be due to rapid decomposition and mineralization of organic materials contributed by sparse vegetation in the hot semi-arid climate as promoted by radiation.

Total nitrogen ranged between 0.50 to $1.81 \mathrm{~g} / \mathrm{kg}$. This result agrees with that of [51] whose study in Bauchi State gave total nitrogen values that ranged from .084 to $.09 \mathrm{~g} / \mathrm{kg},(0.09 \mathrm{~g} / \mathrm{kg}-1$ average); 0.05 to $0.06 \mathrm{~g} / \mathrm{kg}-1$ ( $0.05 \mathrm{~g} / \mathrm{kg}-1 \mathrm{average})$, and 0.7 to $0.09 \mathrm{~g} / \mathrm{kg}-1(0.082 \mathrm{~g} / \mathrm{kg}-1$ average), in different depths TLL1, TLL2, and TLL3 respectively. The total nitrogen values of the soils in the area changed irregularly with depth which could be attributed to influence of continuous cultivation, a common practice in the area that is accompanied by crop residue removal and deforestation [52]

Electrical conductivity ranged between 0.06 and $0.11 \mathrm{ds} / \mathrm{m}$ which was low. Low values of EC indicate non-saline status of the soil. This finding is not agreeing with the results of [53] who obtained EC ranging from 1.88 to $3.30 \mathrm{dsm}-1$, (3.3dsm-1 average); 0.88 to $2.60 \mathrm{dsm}-1$ (1.50dsm-1 average) and 0.90 to $1.08 \mathrm{dsm}-1$ (1.30dsm-1 average) in three profiles respectively in studies carried out in sites within the same ecological zone as the study area.

The values of exchangeable sodium percentage (ESF) were generally below $15 \%$ which is the critical limit for sodicity [54]. The Sodium Adsorption Ratio (SAR) values in the study area are rated low, below the threshold value of 13 for sodic soils [55].

The exchangeable basis of the soils in the study area was generally low. Similar results were obtained by [56]. Calcium and magnesium are the predominant basic cations in the soils. Similar observations have been made in the past for West African soils in general [57]. The findings also agree with those of [58].

The effective cation exchange capacity (ECEC) of the soil is low, an indication that the soils at their natural pH levels, remain low in CEC and therefore have a low capacity to retain nutrients.

\section{Conclusion}

The soil survey of Bagale hills Forest Reserve was conducted to ascertain its current edaphic status because of its vulnerability to different anthropogenic activities over the many years of its existence. The composite soil samples collected from two depths, $0-40 \mathrm{~cm}$ and $40-80 \mathrm{~cm}$, were assessed for physico-chemical properties. Physical properties revealed a preponderance of sand and low percentages of silt and clay. Chemical properties showed that the soil is acidic. Although results varied at the lower, mid and high elevations along the altitudinal gradients, the ANOVA showed no significant difference in the edaphic status of this reserve. The soil of this reserve will therefore require adjustments and intervention to enhance its sustainable development.

Extension activities and capacity building, should be carried out to sensitise the people especially those proximal to this reserve, on its proper utilization. Deforestation, wrong farming methods, bush burning and many other forms of anthropogenic activities detrimental to this ecosystem, could be discouraged as these could lead to soil degradation.

This study can be used as a template in conducting further researches in this category to evaluate the "health status" of other forest reserves in Northern Nigeria and in the whole country.

\section{Compliance with ethical standards}

\section{Acknowledgments}

The authors are grateful to Mr. McDonald and Mallam Haruna Dumne for assisting in data collection and Mr. Yohanna for laboratory analysis of soil samples.

\section{Disclosure of conflict of interest}

If two or more authors have contributed in the manuscript, the conflict of interest statement must be inserted here. 


\section{References}

[1] ADME. (2018). Adamawa State Ministry of Environment, annual progress evaluation report, Divisional Forest Office, Girei, Adamawa State. Nigeria, 15.

[2] Ba AM, Galtima M and Tukur AL. (2014). Assessment of environmental changes in the Fufore area of Adamawa state. Nigeria journal of environmental science, toxicology and food technology, 8, 01-06.

[3] Igboanugo ABI, Omijeh JE and Adegbehin JO.(1990). Pasture floristic composition in different eucalyptus species plantation in some parts of Northern Guinea Savanna zone of Nigeria.agroforestry systems 12, 257-268.

[4] Abdel-Majid AH, Gerald ES and Richard HH. (1987). Soil bulk density and water in filtration as affected by grazing systems. Journal of range management, (40(4), 307-312.

[5] Mirzae i JAK, Barinia M, Hossaini SM and Kohzadi B. (2009). Biodiversity comparison of woody and ground vegetation species in relation to environmental factors in different aspects of Zagros forest. Environmental science. $5(3), 15-18$.

[6] Kutilec M. (2004) Soil hydraulic properties as related to soil structure. Soiltillageresearch, 79(2), 184-275.

[7] Strong CL, Boulter SL, Laid law, MJ, Maunsell SC, Putland D and Kitching RL.(2011). The physical environmental of an altitudinal gradient in the rain forest of Laminton national park, South East Queens land. Nature. 55(2), 251270 .

[8] Carter MR and Ball BC. (1993). Soil porosity, In: Carter, M.R. (ed). Soil sampling and mjethod of analysis. Canadian society of soil scince. Lewis publishers, ]Chelsea,Michigan U.S.A, 453.

[9] Brady NC and Weil RR. (2002).The nature and properties of soil. 13 ${ }^{\text {th }}$ edition. Pearson prentice hall, Inc. PLC Ltd. Indian branch, Delhi,India, 976.

[10] Cassel DK. (1982). Tillage effects on the soil bulk density and mechanical impedance, In: Unger, P.W. and van Doran, D.M (eds). Predicting tillage effects on soil physical properties and processes. ASA-SSSA, Madison, U.S.A 399-430.

[11] Kimmings JP. (1996). Importance of soil and the role of ecosystem disturbance for sustained productivity of cool temperate and boreal forests. Journal of American soil society, 60, 1073, 654.

[12] Pimentel D, Stachow U, Takacs DA and Brubakar HW. (2002). Conserving biological diversity in agricultural and forestry systems Bioscience, 42, 354-362.

[13] MAUTECH. (2018). Meteorology station, Modibbo Adama University of Technology, Yola, Adamawa state, Nigeria.

[14] Keay RWJ, CFA Onochie and DP Stanfield. (1964). Nigerian trees: .keys to the general and index, volume l, revised and reprinted, 31-317.

[15] Naughton JS and the Wolf LL. (1979).General ecology. second edition. Holt Rineheart and Winston inc. U.S.A, 1702.

[16] Cayuela LDJ, Golicher J, Sales Rey and JM Rey -Benayas. (2006b). Classification of a complex landscape using dempster -shafer theory of evidence. International journal of remote sensing, 27, 1951-1971.

[17] Jaiswal PC. (2004). Soil, plant and water analysis. Kalyani publishers, 441.

[18] Black CA. (1965). Methods of soil analysis. Vol.2. American society of agronomy. Madison, Wisconsin U.S.A.

[19] Wilcox LV. (1950). Electrical conductivity. American water works association journal, 42, 775-776.

[20] Walkey A and Black CA. (1947). Critical examination of rapid methods of determining organic carbon in soils. Effect of variation in digestion methods and of inorganic soil constituents. Soilscience, 632-651.

[21] Jackson ML. (1973). Soil chemical analysis, Prentice - Hall of India private limited, New Delhi.

[22] Olsen SR, Cole CV, Watnahe FS and Dean LA.(1954). Estimation of available phosphorus in soils by extraction with sodium bicarbonate. Department of agriculture, 939.

[23] Toth SJand Prince AL. (1949). Estimation of cation exchange capacity and exchangeable Ca, K and Na content of soils by flame photometer technique. Soil science, 67,439-445. 
[24] Lambin EF and Mayfroidt P. (2011). Global land use change, economic globalization and the looming land scacity. Proceeding of National academy of sciences U.S.A, 108 (9), 3465-3472.

[25] Law R. (2001). Phetoty pic and genetic changes due to selective exploitation. Ecology, 2, 323-342.

[26] Malgwi WB and Abu ST.(2011). Variations in some physical properties of soils formed on hilly terrain under different land use types in Nigerian savanna. International journal of science, 1(l).

[27] Usman A. (2015). Biodiversity and species association along altitudinal gradients of the Atlantica mountain range at koma, Adamawa state, Nigeria. Unpublished Ph.D thesis submitted to the Department of forestry and wild life management, Modibbo Adama University of Technology, Yola, Adamawa state. Nigeria, 140.

[28] K aram, DS Arifin, A Radzavi, O Shamsudin, Husni MHA, Abdul-hamid H and Thavakumar S. (2013). Changes in the physico-chemical properties of soils under rehabilitated low land dipterocarps forest at Chikus forest reserve, Perak, Malaysia. The journal of macro trends in applied science, I(l).

[29] Oluwadare DA, Voncir N, Mustapha S and Muhammed GU. (2013) Evaluation and enhancement of available micro nutrient status of cultivated soils of Nigeria guinea savanna using organic and inorganic amendments. 10SR Journal of agriculture and veterinary science (10SR-JAVS) 3(5), 62-68.

[30] Foli S.(2012). Farm characterizations in the Southern and Northern guinea savanna zones of Nigeria: identification of niches for grain legume technologies. Unpublished M.SC. thesis, Wageningen university.

[31] Yakubu M. (2006). Genesis and classification of soils of over different geological formations and surfaces, in the Sokoto plain, Nigeria. Ph.D thesis, soil science and agricultural engineering department, Usman Dan Fodiyo university, Sokoto. (unpublished)

[32] Donahue RL, Raymond MW and Schickline JC. Soils: an introduction to soil and plant growth. Prentice- hall of India. 667.

[33] Esu 1.E. (1991). Detailed soil survey of NIHORT farm of Bunkure, Kano state, Nigeria. Institute for agriculture research, $\mathrm{ABU}$, Zaria.

[34] Kparmwang, T. (1993). Characterization and classification of basaltic soils in the Northern guinea savanna zone of Nigeria. Unpublished Ph. D thesis. Department of soil science, ABU, Zaria, 176

[35] Olujobi OJ. (2016). Comparative effect of selected tree legumes on physico-chemical-properties of an alfisol in Ekiti state. ARPN Journal ofagricultural and biological sciences, 11(3).

[36] Eche NM, Iwuafor ENO, Amapu IY and Bruns MV. (2013). Effects of application of organic and mineral soil amendments in a continuous cropping system for 10 years on chemical and physical properties of an alfisol in Northern guinea savanna zone. International journal of agricultural policy and research, I(4), 116-123.

[37] Morbeg JP and Esu IE. (1991). Characteristics and composition of Nigeria savanna soils. Geoderma, 48, 113-129.

[38] Odunze AC.(2006). Soil properties and management strategies for some sub-humid savanna zone alfisols in Kaduna state. Nigeria. Savannajournal of agricultural research, 22, 3-14.

[39] Brady NC.(1987). The nature and properties of soils. $8^{\text {th }}$ edition Macmilan, New York.

[40] Idoga S, Ibanga IJ and Malgwi WB. (2006). Variation in soil morphological and physical properties and their management implications on a topo sequence in Samaru area, Nigeria, ABU, Zaria, Nigeria,19-25. In: proceedings of the $31^{\text {st }}$ annual conference of soil science society of Nigeria,ABU, Zaria Nov, 13-17.

[41] Maniyunda LM and Malgwi WB. (2011). Chemical properties and management strategies for soils along River Galma, Zaria, Nigeria. In: Adebayo, MKA, Odofin AJ, Osunde AO, Bala A and OyeniyiSO.(eds). Soils resources management, global climate change and food security. Proceedings of the $35^{\text {th }}$ annual conference of SSSN,Minna, Niger state, March $7^{\text {th }}-11^{\text {th }}$.

[42] Riev S and Sposito T. (1991). Fractal fragmentation, soil porosity and soil water properties. Theory of soil science. Society of american journals 55, 1231-1238.

[43] Odunze AC. (2006). Soil properties and management strategies for some sub-humid savanna zone alfizols in Kaduna state Nigeria.Samaru journal of agricultural research by, 22, 3-14.

[44] Landon JR. (1991). Booker tropical soil manual. Longman scientific and technical,Essex, U.K, 474. 
[45] Yakubu M. (2006). Gensis and classification of soils over different geological formations and surfaces in the Sokoto plain,Nigeria.Ph.D thesis. Soil science and agriculture engineering department Usman Danfodiyo University,Sokoto (unpublished).

[46] Agbu PA and Ojanuga AG. (1989). Properties and classification of soils of Dange area of Sokoto state, Nigeria. Samara journal of agricultural research. 6, 37-47

[47] Kparmwang T.(1986). Inherent fertility status of upland and fadama soils in Bauchi state, Nigeria.Noma,12, 1-7

[48] Noma SS, Tanko IJ Yakubu M, Dikko AU, Abdullahi AA and Audu M. (2011). Variability in the physico-chemical properties of the soil of Dundaye district, Sokoto state. Nigeria. Proceedings of the $45^{\text {th }}$ National annual conference of agricultural society of Nigeria,held at the Faculty of agriculture, Usman Danfodiyo University, Sokoto, Nigeria, $24^{\text {th }}-28^{\text {th }}$ October.

[49] Sanda AR, Ogunwale JO, Oluwasemire KO and Raji BA. (2007). Effects of drainage water recycles and irrigation scheduling on soil properties and yield of tomato under a high water table in Northern Nigeria. In: Uyovbisere, E.O., Raji, B.A., Yusuf, A.A., Ogunwale, J.O., Aliyu, L. and Ojeniyi, S.O. (Eds) Soil and water management for poverty alleviation and sustainable environment. Proceedings of the 31th annual conference of SSSN/ABU, Zaria, Nigeria. (59).

[50] Noma SS, Ojanuga AG, Ibrahim SA and Iliya MA. (2004). Detailed soil survey of the Sokoto Rima flood plains of Sokoto,Nigeria.Proceedings of the $29^{\text {th }}$ annual conference of SSS/UNAAB.December, $6^{\text {th }}-10^{\text {th }}$.

[51] Kowal D and knabe DJ. (1972). An agroclimatological atlas of the Northern state of Nigeria, A.B.U press, Zaria. Nigeria.

\section{How to cite this article}

Omijeh JE, Barde MM, Jatau DF and Muhammad AB. (2019). Edaphic status along altitudinal gradients of Bagale hills forest reserve, Adamawa State, Nigeria. World Journal of Advanced Research and Reviews, 4(2), 10-19. 